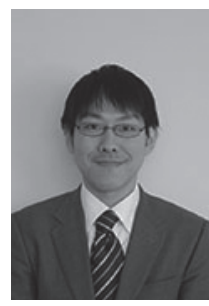

\title{
金ナノ粒子のナノ光学物性に関する研究
}

西山 嘉男*

\section{Study of Nano-Optical Properties of Gold Nanoparticles}

by

\section{Yoshio NISHIYAMA*}

今回縁あって，極限環境部門委員会のご推薦により 執筆する機会をいただきました。私は大学院在籍時よ り分光測定をメインに研究してきた,「計測屋」です. 幾分畑違いではあるのですが，本稿では主に，私が少 し前まで行ってきた，近接場光学顕微鏡を用いた金ナ ノ粒子に関する研究を, 材料分野との関連とともにご 紹介させていただきます.

近接場光学顕微鏡は, 光源のごく近くにしか存在し ない近接場光を利用する少し特殊な方法で, 通常の光 学顕微鏡よりもはるかに小さいものを観測することが 可能です．特に, 金や銀といった貴金属のナノ粒子に 関しては，特徵である表面増強効果がどこで起こって いるのかを直接観測することができます。図 1 には, 近接場光学顕微鏡で観測した棒状の金ナノ粒子（＝金 ナノロッド）の発光像が示してあります。ナノ粒子内 での光の増強は自由電子の集団振動であるプラズモン により起こりますが, 実際にプラズモンの振幅の大き な位置で発光が増大することが観測されます。この顕 微鏡は，他の金属ナノ構造にも適用でき，例えば，金 ナノ粒子を並べた場合には, そのギャップの位置で増 強効果が大きくなることが観測できます．同様に，デ バイスに適用できるような多くの金ナノ粒子を敷き詰 めた構造に関しても，どの場所で増強効果が起こるの かを特定することができました. プラズモンの増強効 果を利用したプラズモニック材料はセンシング分野を はじめとして, 光電変換デバイスなど様々な用途への 応用が実現・検討されています。一方, 近接場光学顕 微鏡に関しては, 市販品でなかなか使い勝手の良いも のはなく, 研究分野でも十分に普及しているとはいえ ないのが現状です，（実際，使用した顕微鏡は，研究室 で自作したものです.）ただ，年々，多様な様式の近接 場光学顕微鏡が開発されるなど, 利便性は高くなって きており，将来的にはプラズモニック材料を設計する ための有用なツールになるのではないかと期待してい ます.

また，私自身はこれに加えて，近接場顕微鏡下でプ ラズモンの寿命を計測することに取り組んでいました。 そのためには, 当時例のなかった, フェムト秒レーザー を用いた時間分解計測法と近接場光学顕微鏡を組み合

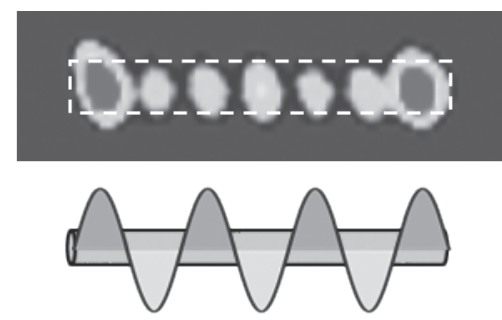

図 1 金ナノロッドの近接場光学像 (上、点線は ナノロッドの概形）および、プラズモンの 振幅を示す波動関数(下)

わせた装置を構築するという課題があったのですが, 大学院時代に培ってきた時間分解計測法のノウハウを 基に，なんとかプラズモンの寿命を決定できる性能を 実現することができました。 それにより，金ナノ粒子 を用いて高い表面増強効果を得るためには，プラズモ ンの長寿命化が不可欠であることを見出すことができ ました。

現在は，所属が変わったことを経緯に，金ナノ粒子 のプラズモンそのものの研究から，ナノ粒子を用いて 他の対象を分析することへ研究がシフトしています. 近年，金ナノ粒子を用いたセンシングは分子の検出だ けではなく，タンパク質などのキラルな分子の識別に も適用できる可能性が指摘されています。実際，金ナ ノ粒子がナノスケールでキラル選択的な光学的性質を 持っていることを，近接場光学顕微鏡で観測すること ができました。これらの結果を背景に，キラルな分子 を識別・定量分析できるような金ナノ粒子構造の作製 や方法論の開発に取り組んでいます。

最後になりますが, 今回紹介させていただいた研究 の大部分は特任助教として勤務した分子科学研究所で 行ってきたものです．指導してくださった岡本裕巳教 授に感謝の意を述べさせていただきたいと思います. また，現在の研究をサポートしていただいている金沢 大学の井村久則教授, また大学院時に研究の基礎を指 導してくださった同志社大学の木村佳文教授に対して も，この場を借りて感謝の意を述べさせていただきた いと思います。 